\title{
Iraqi EFL University Students' Linguistic Strategies in Approaching Warning and Prohibition
}

\author{
Abbas Lutfi Hussein ${ }^{1} \&$ Saad Qasim Khalaf ${ }^{1}$ \\ ${ }^{1}$ College of Arts, Mustansiriyah University, Baghdad, Iraq \\ Correspondence: Saad Qasim Khalaf, College of Arts, Mustansiriyah University, Baghdad, Iraq. Tel: \\ 964-7901-669-738.
}

Received: September 16, 2018

Accepted: November 1, 2018 Online Published: November 3, 2018

doi: $10.5539 /$ elt.v11n12p11

URL: https://doi.org/10.5539/elt.v11n12p11

\begin{abstract}
This paper aims at detecting Iraqi EFL students' ability in recognizing and producing the speech acts of warning and prohibition, finding the reasons behind their failure and attempting to find possible solutions. The data are responses of 60 fourth year Iraqi EFL college students who participated to answer a two-part test of recognition and production. It is hypothesized that the Iraqi EFL learners commit more errors in producing SAs of warning and prohibition than recognizing these two SAs, they find more difficulty in handling the SA of prohibition than of warning, they show a tendency towards using a particular strategy to express the SAs of warning and prohibition, and they also confuse the SAs of warning and prohibition with other relevant SAs at the recognition and production levels. The paper concludes that Iraqi EFL learners recognize warning expressions better than those conveying prohibition. They also show sufficient awareness in issuing warning strategies in various situations. By contrast, they display a poor awareness of using various strategies in performing the SA of prohibition. Furtherly, the students' level in recognizing the SAs of warning and prohibition is higher than their level in producing these SAs. Correspondingly, in producing the SAs of warning, Iraqi EFL learners show a higher preference for using negative imperative, modals and if-conditional strategies more than other types in most of the situations, whereas in communicating the SA of prohibition, they employ negative imperatives and modals more than any other construction.
\end{abstract}

Keywords: warning, prohibition, EFL students, test, recognition, production

\section{Introduction}

\subsection{General Background}

Among the most widely used types of speech acts (SAs), warning and prohibition are considered critical to learn. They have many applications in everyday communication. Warning and prohibition play an essential role in educating people and reducing injuries and fatalities, and they, therefore, worth better production and recognition.

According to Allan (1986), warning is telling someone to do or not to do something for his benefit. In other words, the speaker $(\mathrm{S})$ informs the hearer $(\mathrm{H})$ that something dangerous or unpleasant may happen in the future so that they can try to avoid it. For example:

1). I warn you against walking alone at night.

In (1), warning is about possible danger or difficulty, which is likely to happen. Warning can also be issued in many other implicit structures other than by using the word 'warn' itself. It can be expressed as in the following examples:

2). a. Sugary drinks cause tooth decay.

b. You will get hurt if you do not slow down.

In (2) above, warning is implicitly encoded using declarative (a) and conditional (b) in which $\mathrm{S}$ tries to warn $\mathrm{H}$ about undesirable consequences on the part of $\mathrm{H}$ as a result of his behavior.

Prohibition, on the other hand, is simply defined as the act of stopping something being done or used, primarily by law, i.e., it indicates forbidding which is to order somebody not to do something (Allan, 1998; Eastwood, 2002). For example: 


\section{3). a. Smoking is prohibited in public places.}

\section{b. Parking is strictly forbidden between these gates.}

Like warning, prohibition can also be expressed implicitly. For example:

4). a. Don't disturb!

b. Keep out.

\subsection{The Problem}

The $\mathrm{H}$ of the following utterance, for example, might get confused whether it is warning or prohibitions:

\section{5). You can't park here.}

It is not obvious whether the $\mathrm{S}$ in (5) is trying to warn or prohibit the H. This confusion between warning and prohibition may lead students to overlap them. One can also argue that advanced Iraqi EFL students find difficulty in handling these two SAs. Therefore, a study is needed to the bridging of this gap.

\subsection{Rationale of the Study}

Generally speaking, the types of previous studies conducted with respect to warning and prohibition deal with each SA individually. Besides, other studies are comparative between two languages especially in religious texts. Moreover, by surveying the practical type of studies, it has been found that there has been no one practical study which directly relates the two SAs of warning and prohibition to students' ability to differentiate between the two SAs in question. Cases in point are the following: Kadhim (2012) compares between the warning and threat acts in two languages. Al-Shafie and Al-Jubbory (2015) investigate the use of warning and threatening by Iraqi EFL learners in situational dialogues. Al-Saaidi, Al-Shaibani and Al-Husseini (2013) conduct a contrastive study of prohibition in two languages based on selected Biblical and Quranic Verses. Betti, Igaab and Al-Ghizzi (2018) compare prohibition to permission and obligation as used by Iraqi EFL learners. It is clear that there are differences between this study and the above-mentioned studies.

According to Creswell (2012), a problem should be researched if the study will fill a gap or void in the existing literature. Therefore, this study will cover a topic which is, according to the researchers' best knowledge, not addressed in the published literature so far despite the noticeable affiliation between these two SAs that remains a challenge for EFL learners and scholastic researchers. The absence of practical studies with respect to warning vis-à-vis prohibition in relation to EFL learners' performance in particular has led the researchers to investigate the two SAs to illustrate the points of similarity and difference between these two SAs, and to investigate the ability of advanced Iraqi EFL learners to differentiate between the two SAs in English.

\subsection{Aims, Hypotheses, Limits, and Value}

This study aims at detecting Iraqi EFL learners' ability in recognizing and producing the SAs of warning and prohibition, finding the reasons behind students' failure and attempting to find possible solutions, and exploring the main strategies that Iraqi EFL learners employ in performing the SAs of warning and prohibition in particular situations. These three objectives can be carried out through the following hypotheses:

1) Students commit more errors in producing SAs of warning and prohibition than recognizing these two SAs.

2) Iraqi EFL college students find more difficulty in handling the SA of prohibition than of warning.

3) Iraqi EFL learners show a tendency towards using a particular strategy to express the SAs of warning and prohibition, i.e. directly by employing negative imperative constructions or indirectly by employing modals than other strategies.

4) They also confuse the SAs of warning and prohibition with other relevant SAs at the recognition and production levels.

This study is limited to the pragmalinguistic and sociopragmatic analysis of the SAs of warning and prohibition as recognized and produced by Iraqi EFL college students. It derives its value from its attempt to bridge a gap in the literature on the overlapping between the SAs of warning and prohibition. It is expected that the Iraqi EFL college students will learn the SAs of warning and prohibition better if they know their different forms and usages. This study is also of benefit to Iraqi EFL teachers as well as researchers in the field of linguistics who are interested in the various applications of the SAs theory. The procedures in this study are:

1) Designing a test of recognition and production to be administrated to a sample of Iraqi EFL college fourth-year students of Mustansiriyah University, College of Arts, Department of English,

2) Conducting data collection and analysis based on the responses of the students, 
3) Identifying the strategies followed by the subjects and specifying the difficulty and errors in their performing of the SAs of warning and prohibition,

4) Finding reasons and causes behind student's failure in recognizing and producing the SAs of warning and prohibition, and

5) Drawing results, conclusions, recommendation and suggestions for further studies.

\section{Literature Review}

\subsection{Warning vs Prohibition}

Prohibitions are apparently directive according to Searle's (1969) definition, whereas warning is partly, but not primarily, representative. Searle (1969) confirms that the distinction between illocutionary force indicators (IFIDs) and proposition indicators is very useful in constructing an analysis of illocutionary acts (such as warning and prohibition). However, distinguishing a certain SA from another is somehow pragmatically problematic as Quirk et al. (1985) stress that it is not always likely to make a clear-cut distinction because the illocutionary force varies depending on the relative authority of $\mathrm{S}$ and $\mathrm{H}$ and on the relative benefits of action (A) to each. However, depending on the features of both warning and prohibition, it seems that the following are the most evident principles by which, warning and prohibition can be recognized:

\subsubsection{Intentionality and Purpose.}

According to Searle (1992), the form of the utterance:

\section{6). Do you think this is a parking space?}

may be used for different SAs, depending on $\mathrm{S}$ and $\mathrm{H}$ and on the actual circumstances. If uttered by a car owner to a passer-by, it may be a simple request for information; if uttered by a policeman, it might be a warning; and if uttered by the farmer on whose land H's car is parked, it might be a prohibition. In all these cases the actual form of the utterance is irrelevant. What count are the conditions, the situation, the intentions and so on.

\subsubsection{Authority and Power}

Lyons (1977), Allan (1986) and Eastwood (2002) assure the fact that in issuing prohibition, S should have the authority or power to impose his will upon the H. For example, in:

\section{7). Students must not use dictionaries in the examination.}

$\mathrm{S}$ is the authority, the person who feels the necessity to stop the use of dictionaries. Thus, when prohibiting, Ss necessarily have some authority over their Hs (Searle \& Vanderveken, 1985). On the other hand, warning is invitational (negative advise) (Allan, 1986) which is only intended to inform $\mathrm{H}$ about an unfavourable state (Fraser, 1998). Consider the utterance:

\section{8). Walking alone at night is dangerous.}

In (8), the $\mathrm{S}$ only gives $\mathrm{H}$ nonmandatory information about a dangerous situation.

\subsubsection{Optionality}

This principle is essential in distinguishing warning from prohibition. In the prohibition case, $\mathrm{H}$ has no space of optionality to do or not to do A. This is due to the instructive nature of prohibitions, i.e., they are non-negotiable utterances according to which S restricts H's option and freedom (Allan, 1986), and thus threatens H's NF (Brown \& Levinson, 1987), whereas in warning, the case is different where $\mathrm{H}$ has optionality to heed or not (Crystal, 2010). This means that warning belongs to the negotiable directives, i.e., does not impose an instruction, which is against the nature of prohibition. To illustrate this meaning, consider (9) and (10):

9). Mexican law citizens are not allowed to have dual Citizenship. (Prohibition) (Mayor, 2013).

10). If you don't lock your car, it might not be here when you get back. (Warning) (Goddard \& Wierzbicka, 2013).

\subsubsection{Cost- Benefit Scale}

The fourth principle is the cost- benefit standard, i.e. SA being beneficial/costly to either S or H. Psychologically, warning is an act that is used to warn people from certain bad things. Thus, if a $\mathrm{S}$ tells a $\mathrm{H}$ to refrain from a behavior which will enable him to easily and directly achieve a goal, then the $\mathrm{H}$ makes a cost-benefit analysis and depends on certain psychological factors to accept this warning (Green, 2013). This means that in warning, $\mathrm{H}$ is the beneficiary. In prohibition, $\mathrm{S}$ is the benefit recipient (Haverkate, 1984).

\subsubsection{Politeness and Social Factors}

People use the indirect SA because of the view that considers it more polite especially in certain societies (Finch, 
2000). According to Brown and Levinson (1987), warning is the case where "doing the FTA is primarily in H's interest", and therefore, no face redress is necessary (ibid). However, prohibition is highly FTA as it impedes the addressee's freedom (Allan, 1986; Brown \& Levinson, 1987); it projects S's power status and authoritativeness and stresses the inequality of power between $\mathrm{S}$ and $\mathrm{H}$. Further, politeness is associated with different illocutionary acts since its maxims such as "Generosity, Tact, Approbation and Modesty" are applied to different contexts.

11). You must not come late.

12). I cannot lend you my car.

The two examples above have the IF of prohibition, which are supposed to be more polite for two reasons: (a) because "they imply benefit to $\mathrm{H}$, and (b) because they imply cost to speaker" (ibid).

2.1.5 Illocutionary Force Indicating Devices (IFIDs)

Searle (1969) suggests that IFs can be defined by providing, for each A, necessary and sufficient conditions

for the performance of A. Certain syntactic and semantic devices, such as mood and explicit performative verbs, are employed to realize the IF. Searle (1969) also asserts that there is a regulation to the uptake that the IFID can only be communicated if felicity conditions (FCs) are satisfied. Similarly, Yule (1996) asserts that the H can recognize the speaker's intended illocutionary force (IF) by considering two things: IFIDs and FCs.

Table 1 below illustrates the FCs of both SAs of warning and prohibition.

Table 1. FCs of warning vs. prohibition

\begin{tabular}{|c|c|c|c|}
\hline Types of Condition & \multicolumn{2}{|c|}{$\begin{array}{l}\text { The Formulation of the Condition in the case } \\
\text { of Warning (Searle, 1969) }\end{array}$} & $\begin{array}{l}\text { The Formulation of the Condition in the } \\
\text { case of Prohibition (Allan, 1998) }\end{array}$ \\
\hline $\begin{array}{l}\text { The propositional } \\
\text { condition }\end{array}$ & \multicolumn{2}{|c|}{ Future event or state, etc. $\mathrm{E}$ is predicted of $\mathrm{H}$} & $\mathrm{S}$ prohibits $\mathrm{H}$ from doing act $\mathrm{A}$ \\
\hline \multirow{2}{*}{$\begin{array}{l}\text { The Preparatory } \\
\text { Condition }\end{array}$} & \multicolumn{2}{|c|}{$\begin{array}{l}\text { 1- } \mathrm{S} \text { thinks } \mathrm{E} \text { will occur and it is not in H's } \\
\text { interest }\end{array}$} & \multirow{2}{*}{$\begin{array}{l}\text { S has reason to believe that } \mathrm{H} \text { should not } \\
\text { do A }\end{array}$} \\
\hline & \multicolumn{2}{|c|}{$\begin{array}{l}\text { 2-S believes it is not evident to } \mathrm{H} \text { that } \mathrm{E} \text { will } \\
\text { happen }\end{array}$} & \\
\hline $\begin{array}{l}\text { The Sincerity } \\
\text { Condition }\end{array}$ & \multicolumn{2}{|c|}{$\mathrm{S}$ thinks $\mathrm{E}$ is not in H's best interest } & $\mathrm{S}$ wants $\mathrm{H}$ not to do $\mathrm{A}$ \\
\hline ILLOC Intention & \multicolumn{2}{|c|}{$\begin{array}{l}\text { The uttering of words counts as an undertaking } \\
\text { to the effect that } E \text { is not in H's best interest }\end{array}$} & $\begin{array}{l}\mathrm{S} \text { reflexively intends } \mathrm{U} \text { to be recognized } \\
\text { as a requirement on } \mathrm{H} \text { not to do } \mathrm{A}\end{array}$ \\
\hline \multicolumn{4}{|c|}{ Note. $\mathrm{E}=$ Event; $\mathrm{A}=$ =Action; $\mathrm{U}=$ Utterance. } \\
\hline \multicolumn{4}{|c|}{$\begin{array}{l}\text { Table } 1 \text { above along with the previous discussion manifest that the following points, shown in Table (2) below, can } \\
\text { be followed in distinguishing the SAs of warning and prohibition: }\end{array}$} \\
\hline \multicolumn{4}{|c|}{ Table 2. Warning vs prohibition } \\
\hline \multicolumn{2}{|c|}{ Conditions } & Warning & Prohibition \\
\hline \multicolumn{2}{|l|}{ To the S's benefit } & & $\mathrm{X}$ \\
\hline \multicolumn{2}{|l|}{ To the H's benefit } & $\mathrm{X}$ & \\
\hline \multicolumn{2}{|l|}{ From S's perspective } & $\mathrm{X}$ & $\mathrm{X}$ \\
\hline \multicolumn{2}{|l|}{ S controls outcome } & & $\mathrm{X}$ \\
\hline \multicolumn{2}{|l|}{ H controls outcome } & $\mathrm{X}$ & \\
\hline \multicolumn{2}{|l|}{ Cooperative } & $\mathrm{X}$ & \\
\hline \multicolumn{2}{|l|}{ Directive } & $\mathrm{X}$ & $\mathrm{X}$ \\
\hline \multicolumn{2}{|c|}{ Assertive (Representative) } & $\mathrm{X}$ & \\
\hline
\end{tabular}


FTA (damages NF)

$\mathrm{X} \quad \mathrm{X}$

Note. $\mathrm{FTA}=$ Face Threatening Act; $\mathrm{NF}=$ Negative Face.

\subsection{A Model Analysis of the SAs of Warning and Prohibition's Strategies}

Depending on the aims of this study, a two-dimensional model, i.e. pragmalinguistic and sociopragmatic, is required to measure the performance of Iraqi EFL performance of the SAs of warning and prohibition in order to get at a corresponding pragmatic analysis in English. The researchers will apply Searle's version of SA theory amalgamated with the warning and prohibition features supported by Haverkate (1984), Brown and Levinson (1987), and Allan (1986). Such applicable amalgamated model can be used for the identification of each SA in terms of the situational factors influencing the choice of language and the description of its linguistic realization in English. Thus, this model will consist of: sociopragmatic distinctive method and pragmalinguistic realization scheme. The two components of the model will be incorporated with the aforementioned features (Table 2) which illustrate the pragmatic values that have been found to be criterial in the discrimination of the SAs of warning and prohibition. This model which is constituted from different theories, styles, ideas and cases can be a useful instrument to obtain a systematic awareness of the SAs of warning and prohibition.

\subsubsection{Brown and Levinson's (1979) Model (Sociopragmatic Model)}

Since Brown and Levinson's (1979) account of the situational factors influencing the choice of language has a prominent place in many empirical types of research, their factors (ibid), i.e. status (STAT), the social distance (SD) and the relative power (REL. P.) will be the base of building up the situations (Sit.) of the test of the practical part of this study, i.e. Sit. Type A, Sit. Type B, and Sit. Type C as clarified below:

Sit. Type A - Status, i.e., whether $\mathrm{S}$ is superior, inferior or equal to $\mathrm{H}$ in position,

Sit. Type B - Social Distance, i.e., whether the $\mathrm{H}$ is familiar or non-familiar to $\mathrm{S}$, and

Sit. Type C - Power, i.e. whether $\mathrm{S}$ addresses $\mathrm{H}$ with/without solidarity.

2.2.2 A Model of the Analysis of the SAs of Warning and Prohibition's Strategies (Pragmalinguistic Model)

According to Wolfson (1989), studying SAs of an L2 requires an accurate understanding of the linguistic possibilities available in that language for SAs realization. Thus, the second component of the adopted model will include a collection of the linguistic strategies of of warning and prohibition for the analysis of the data of the subjects'performance of each SA. Diagram (7) below summarizes the linguistic strategies that are considered by prominent scholars of linguistics to realize the SAs of warning and prohibition in English. 


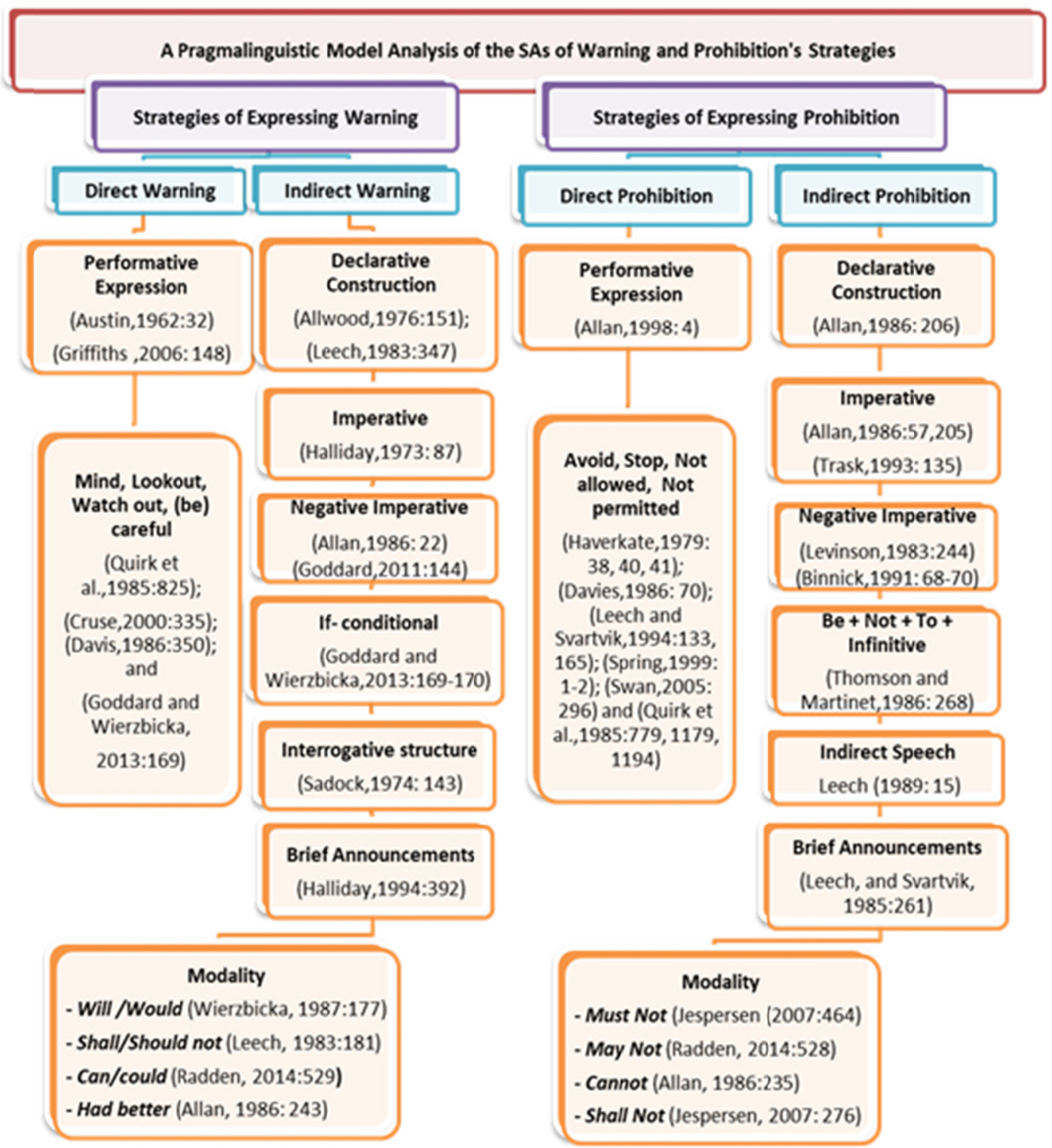

Diagram 1. Model strategies of warning and prohibition in English

\section{Methods}

\subsection{Subjects}

The study includes 60 EFL undergraduate Fourth year students randomly chosen from Department of English, College of Arts, Mustansiriyah University. The subjects at this level range in age between 22 and 24. They are native speakers of Arabic having the same college EFL background. The reason behind choosing 4th-year students is that they are supposed to achieve much progress as EFL learners before graduation.

\subsection{The Test}

\subsubsection{Test Construction}

In order to achieve the objectives of the study and verify its hypotheses, a two-part test of recognition (Part One) and production (Part Two) (See Appendix A) was designed to be administrated to a sample of Iraqi EFL college fourth-year students of Mustansiriyah University, College of Arts, Department of English. The test was carried out on the $4^{\text {th }}$ of March 2018.

The first part of the test consists of twenty situations of warning and prohibition. It takes the form of a recognition test to reveal the subjects' ability to recognize the SAs of warning and prohibition. In this part, the subjects are also 
required to distinguish SAs of warning and prohibition from another related speech acts namely advising, requesting, commanding and threatening which are furtherly included in extra five situations. The subjects are required to choose the correct choice from a variety of four options.

The second part of the test is intended to elicit information about the students' abilities, at the production level, to issue the SAs of warning and prohibition according to specific contextual factors. Thus, it is introduced as an elicitation procedure (Corder, 1982). This part contains twenty situations. The respondents, therefore, are asked to issue the SAs of warning and prohibition according to different situations. This is done deliberately to identify the most common strategies used by them to express the SAs of warning and prohibition.

According to Geis (2006), social ranks and positions are critical to determining what communicative action the initiator means to engage the responder in. Therefore, situations in both parts of the test are adopted from various sources according to Brown and Levinson's (1979) contextual factors:

Sits. Type A: A superior $S$ talks to a familiar $H$ with solidarity

Sits. Type B: A superior $S$ talks to a familiar $H$ without solidarity

Sits. Type C: A $S$ talks to an equal and familiar $H$ with solidarity

\subsubsection{Test Validity and Reliability}

The test requires two essential characteristics, i.e., validity and reliability; otherwise, the accuracy statements about it will be questionable (Hatch \& Farhady, 1982).

Test validity indicates the extent according to which the test truly evaluates what it claims to evaluate. Test validity is of two types: content validity and face validity. Content validity has no statistical values; it involves "the systematic examination of the test content to determine whether it is a representative sample of the behaviour domain to be measured" (Crocker \& Algina, 1986). It depends on a hypothetical basis for presuming if a test measures all domain of a standard.

A test is said to have content validity once it contains suitable items that are carefully selected. Items are selected in order to meet the test requirement which is formulated through a careful study of the subject domain (ibid). To ensure content validity, the test is carefully built to give no room for examining the SAs save for the ones intended to be included, i.e., SAs of warning and prohibition and differentiating them from other related ones like commanding, advising, requesting, and threatening. As for face validity, it is associated with the way the test seems to the learners, test administrators and so on (Harris, 1969). To achieve this objective, the test was revised by a jury of experts (See Appendix B).

Test reliability denotes the extent according to which a test remains constant and firm in order to obtain the required findings. When the test is consistent with itself throughout the time, it is called a reliable test. This means that reliability can be achieved once its scores remain relatively stable on repeated attempts, i.e., from one administration to another (Harrison, 1983). One method of estimating test reliability is test-retest (Harris, 1969). Thus, a sample of the subjects was exposed to the test twice within three days. This sample involved twenty-five randomly selected students in their fourth-year of Department of English, College of Arts, Mustansiriyah University.

The correlation between the scores of the two tests was calculated by using the Kuder-Richardson formula:

$$
\mathrm{R}=\frac{\mathrm{N}}{\mathrm{N}-1} \quad\left(1-\frac{\mathrm{m}(\mathrm{N}-\mathrm{m})}{\mathrm{NX}^{2}}\right)
$$

where

$\mathrm{R}=$ reliability

$\mathrm{N}=$ the number of items in the test

$\mathrm{m}=$ the mean of the test score

$\mathrm{X}=$ the standard deviation of the test scores

The computation of the results has shown that the reliability of the test amounted to (83\%) which is a highly positive correlation (Heaton, 1988).

\subsubsection{Scoring Scheme}

Scoring scheme is the way according to which the obtained results are appropriately interpreted, thus, to ensure an objective scoring of the test; a scoring scheme has been adopted. Each participant, in part 1, is required to choose 
only one correct option at the recognition level. Scores are equally distributed over the items of Part 1 and 2, i.e., the recognition and production level. Two marks are given to each correct answer and zero mark for the incorrect one. Spelling mistakes are ignored. The items that are left without response by the subjects are also given zero mark because they give the impression that the subjects fail to provide the appropriate answer. To measure the central tendency of the subjects, the basic calculations of percentage has been adopted as a statistical device to find out the mean score. In this respect, Butler (1985: 30) mentions that the mean score is the average subject response to an item. It is formed by adding up the number of the correct answers of all subjects for the item and dividing that total by the number of the subjects. Moreover, Mousavi (1999: 213) states that the mean is the most commonly used and most generally valid measure of the central tendency of a distribution. He illustrates that in the following formula:

$$
\widehat{X}=\frac{\mathrm{X} 1+\mathrm{X} 2+\mathrm{X} 3+\cdots \cdot+\mathrm{Xn}}{\mathrm{N}} \quad \text { which is usually written as } \quad \hat{\mathrm{X}}^{\curvearrowleft}=\frac{\Sigma X}{\mathrm{~N}}
$$

where

$\mathrm{X}=$ the mean, $\mathrm{X}=$ raw score, $\Sigma=$ the sum of, $\mathrm{N}=$ the number of subjects.

The results of the subjects' responses at this level are rendered into percentages, according to the below formula, which are then compared with each other.

$$
\frac{\text { Number of correct responses per item } \times 100}{60 \text { (number of subjects) }}=100 \%
$$

\subsubsection{Pilot Study}

The significance of the pilot study is that it illustrates the required time to respond to the items of the test and discloses the effects in individual items that are not noticed in writing the test. In order to examine the efficiency of data collecting method, the suitability of the situations as well as investigating any gaps that may affect the appropriate application of the data collection instrument, a random sample consisting of a twenty five students was exposed to the test in advance on the 25th of February 2018.

\subsubsection{Administration of the Test}

The main test was carried out on the 4th of March 2018. The subjects were given 90 minutes. When the students are seated for the test, they were precisely informed on how to respond to the test items. What they were required to do in answering the test questions was demonstrated to them in English and sometimes in Arabic particularly when needed, as recommended by Olshtain and Cohen (1983) who believe that the respondents' native language should be used to make them fully understand what they are required to do. Besides, they (ibid) think that giving instructions in the L2 may bias the subjects towards using particular expressions, the matter which undoubtedly affects the results of the study. Further, they were informed that the test is intended to collect data devoted for research aims and that it will not affect their marks. To save time and effort, they were requested to respond on the test sheet. To avoid any inconvenience, they were informed not to write their names on the test paper save their age and gender.

\section{Data Analysis}

This section describes the responses of the subjects in recognizing the SAs of warning and prohibition (Part One) and producing them (Part Two). Then, the recognition results of the SA of warning are compared to its production results. The same procedure is used with prohibition. After that, the overall performance of warning, i.e. recognition and production, is ultimately compared to that of prohibition.

\subsection{Analysis of Subjects' Recognition of the SAs of Warning and Prohibition}

Table 3 below illustrates that recognizing the SAs of warning and prohibition realized by the indirect constructions is more difficult than recognizing these two SAs when realized by the direct ones because the IFIDs are not sufficient engough. This is supported by the percentage of the mean score of the direct constructions for both SAs which is $(79 \%)$ in comparison to that of the indirect ones which is $(57 \%)$. 
Table 3. Recognition percentage of the SAs of warning vs. prohibition

\begin{tabular}{lllll}
\hline \multirow{2}{*}{ SA } & & Recognition Perc. per Directness & $\begin{array}{l}\text { Recognition Perc. } \\
\text { Per SA }\end{array}$ & $\begin{array}{l}\text { Recognition } \\
\text { Perc. of both SAs }\end{array}$ \\
\hline \multirow{2}{*}{ Warning } & $\begin{array}{l}\text { Implicit } \\
\text { Explicit }\end{array}$ & $\begin{array}{l}72.38 \% \\
87.50 \%\end{array}$ & $79.94 \%$ & \\
& & & & $68.75 \%$ \\
\multirow{2}{*}{ Prohibition } & Implicit & $42.62 \%$ & $57.56 \%$ & \\
& Explicit & $72 \%$ & & \\
\hline
\end{tabular}

Note. Perc. $=$ Percentage.

However, Table 3 above also illustrates the overall percentage of the incorrect responses of the subjects as (20\%) for warning and $(42 \%)$ for prohibition. These results reveal the ability of the learners to recognize and distinguish the SA of warning better than that of prohibition as illustrated by Figure 1 below.

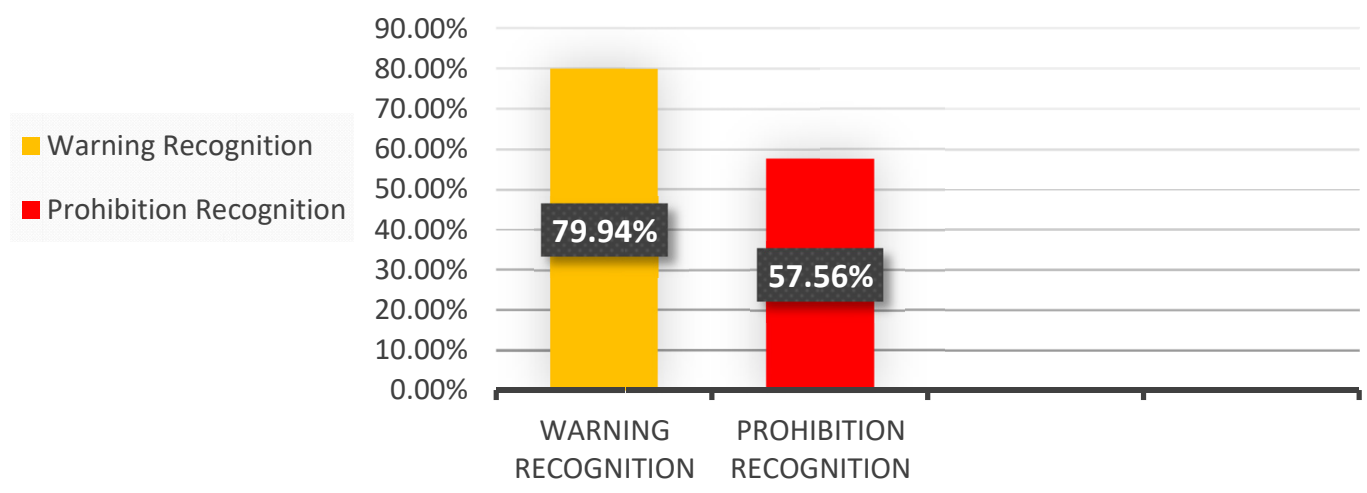

Figure 1. Subjects' recognition of the SAs of warning and prohibition

Figure 1 shows that Iraqi EFL college students find more difficulty in recognizing the SA of prohibition than of warning. To use the mean score as an indicator, the learners' success amounts to $(80 \%)$ in recognizing the SA of warning and to (57\%) in that of prohibition. Finally, the overall percentage of the subjects' successful recognition of both SAs of warning and prohibition amounts to (68\%) which is to be compared with the percentage of subjects' production of these two SAs analysed in the next section.

The scoring of the learners' performance at the recognition level illustrates that the learners are more influenced by the linguistic realizations of the SAs than by the contextual factors affecting those realizations. This is obvious from their success in recognizing SAs made through direct constructions more than in recognizing SAs performed via indirect constructions.

\subsection{Analysis of Subjects' Production of the SAs of Warning and Prohibition}

The analysis of the data concerning strategies used to express the SAs of warning and prohibition reveals that the subjects employ a variety of strategies. However, it can be noticed that the indirect strategies are widely produced while the direct ones rarely attract.

\subsubsection{Warning Production in Types A, B and C situations}

The overall subjects' behaviour in issuing the SA of warning in response to all situations indicates that those who prefer using indirect strategies (55\%) are much more than those who prefer the direct strategies $(16 \%)$. However, the learners' understanding of the situations of Type A and B (77\%) are much better than their coping with those of Type C (61\%) as illustrated by Table 4 below. 
Table 4. Perc. of warning production in types, A, B and C situations

\begin{tabular}{llll}
\hline Sit. Type & Direct Warning & Indirect Warning & Total Av. Perc. per Sit. \\
\hline A & $12.77 \%$ & $63.78 \%$ & $76.55 \%$ \\
B & $11.24 \%$ & $66.64 \%$ & $77.88 \%$ \\
C & $25 \%$ & $36.65 \%$ & $61.64 \%$ \\
Total Av. Perc. of Directness -A.B.C & $16.33 \%$ & $55.69 \%$ & \\
Perc. of Warning Production & & & $72 \%$ \\
\hline
\end{tabular}

Note. Av. $=$ Average; Perc. $=$ Percentage.

As a result, the total average percentage of the subjects' production of the SA of warning in Types A, B, and C amounts to $(72 \%)$ which can be considered as an indicator that the learners are mostly able to cope well with SA of warning.

\subsubsection{Prohibition Production in Types A, B and C Situations}

By contrast, the subject's performance in the situations of prohibition in Types A, B, and C, as Table 5 below relatively manifests that they tend to use indirect strategies (35\%) to express the SA of prohibition more than direct ones $(10 \%)$. Concerning their understanding of the situations of all types, it can be said that there is no significant difference in their responses, i.e. it is relatively the same (45\%).

Table 5. Perc. of prohibition production in types A, B and C situations

\begin{tabular}{llll}
\hline Sit. Type & Direct Prohibition & Indirect Prohibition & Total Av. Perc. per Sit. \\
\hline A & $12.49 \%$ & $33 \%$ & $45.49 \%$ \\
B & $9.44 \%$ & $34 \%$ & $43.44 \%$ \\
C & $8.33 \%$ & $38.73 \%$ & $47.06 \%$ \\
Total Av. Perc. of Directness -A.B.C & $10.09 \%$ & $35.24 \%$ & \\
Perc. of Prohibition Production & & & $45.33 \%$ \\
\hline
\end{tabular}

Note. Av.$=$ Average; Perc. $=$ Percentage.

Table 5 above illustrates that the total average percentage of the subjects' production of the SA of prohibition in Types A, B, and C amounts to (45\%) which can be taken as an indicator that more than half of the learners are mostly unable to cope well with SA of prohibition regardless the situation type. These results reveal that the subjects' warning production is better than their prohibition production as illustrated by Figure 2 .

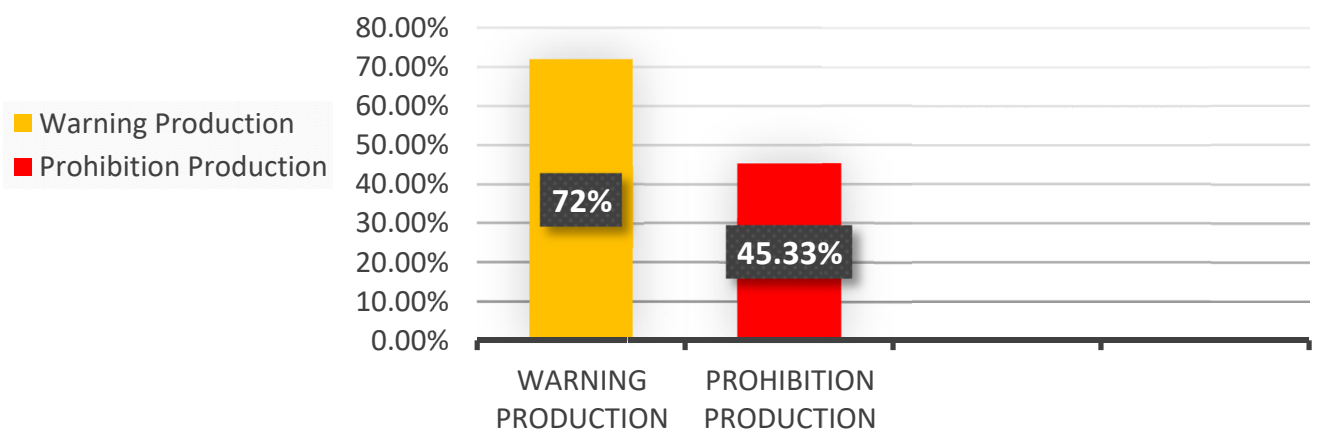

Figure 2. Subjects' production of SAs of warning and prohibition

Concerning the subjects' production of both SA of warning and prohibition, Table 6 below shows that the percentage amounts to $(58 \%)$ which is lower than their percentage in recognizing both SAs, which amount to 
(68\%). It is clear that those students commit more errors in producing SAs of warning and prohibition than in recognizing these two SAs.

Table 6. Subjects performance perc. of warning and prohibition

\begin{tabular}{llll}
\hline Percentage & Warning & Prohibition & Total Av. Perc. \\
\hline Perc. of Subjects' Recognition & $79.94 \%$ & $57.56 \%$ & $68.75 \%$ \\
Perc. of Subjects' Production & $72 \%$ & $45.33 \%$ & $58.67 \%$ \\
Av. Perc. of Subjects' Performance (Recog. \& Produc.) & $75.97 \%$ & $51.45 \%$ & $63.71 \%$ \\
\hline
\end{tabular}

Note. Av. $=$ Average; Perc. $=$ Percentage.

Finally, Table 6 manifests that the percentage of the subjects' performance, i.e. in recognizing and producing each SA, amounts to $(80 \%)$ for the SA of warning and to $(51 \%)$ for the SA of prohibition. The overall performance (recognition and production) of both SAs can be illustrated by Figure 3 below:

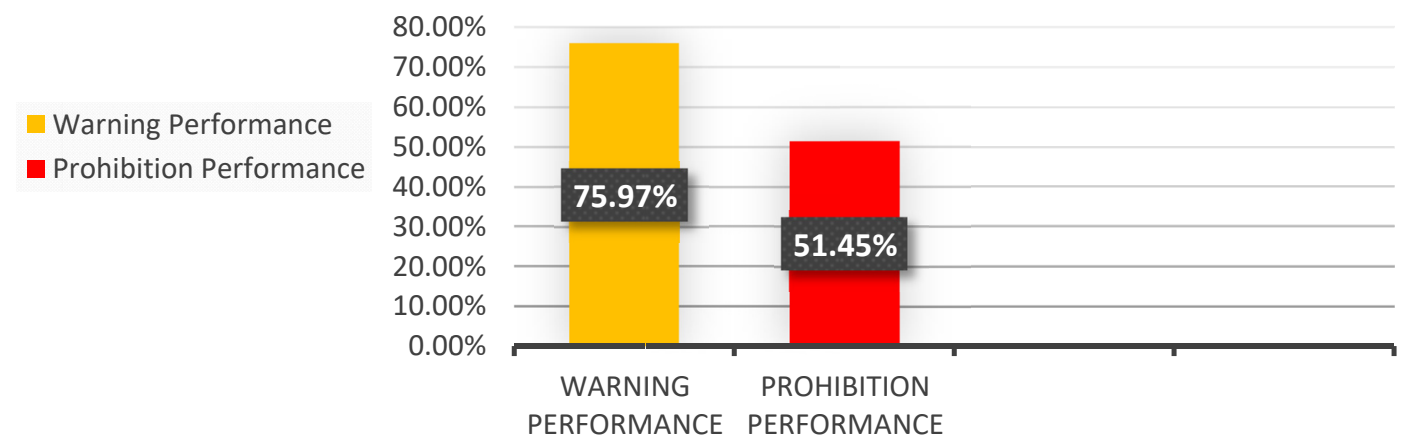

Figure 3. Subjects' performance of the SAs of warning and prohibition

It is evident from Figure 3 above that Iraqi EFL college students find more difficulty in handling the SA of prohibition than of warning.

\subsection{Subjects' Tendency to Warning and Prohibition Strategies}

Table 7 below illustrates that the subjects concentrate on using the strategies of negative imperatives (47.76\%), modals (41.65\%), and if conditional (42.63\%) in expressing the SA of warning.

Table 7. Total percentage of warning strategies employment

\begin{tabular}{|c|c|c|c|}
\hline \multicolumn{3}{|l|}{ Subjects' Strategies } & Recognition Perc. per Item \\
\hline \multirow{6}{*}{ Direct Warning Construction } & \multicolumn{2}{|l|}{ If Conditional } & $42.63 \%$ \\
\hline & \multicolumn{2}{|l|}{ Imperative } & $16 \%$ \\
\hline & \multicolumn{2}{|c|}{ Negative Imperative } & $47.76 \%$ \\
\hline & \multicolumn{2}{|c|}{ Indirect Speech } & $3.26 \%$ \\
\hline & \multicolumn{2}{|l|}{ Modal } & $41.65 \%$ \\
\hline & \multicolumn{2}{|l|}{ Declarative } & $15 \%$ \\
\hline \multirow{2}{*}{ Indirect Warning Construction } & Performative & Warn/Warning & $20.68 \%$ \\
\hline & Lexical Verbs & Watch out/Lookout/Mind & $28 \%$ \\
\hline
\end{tabular}

However, the subjects' production of the SA of prohibition is primarily performed by the employment of negative imperative and modal strategies more than other strategies as Table 8 below illustrates. 
Table 8. Total percentage of prohibition strategies employment

\begin{tabular}{|c|c|c|c|}
\hline \multicolumn{3}{|l|}{ Subjects' Strategies } & Recognition Perc. per Item \\
\hline \multirow{6}{*}{ Direct Prohibition Construction } & \multicolumn{2}{|l|}{ Declarations } & $9.93 \%$ \\
\hline & \multicolumn{2}{|l|}{ Imperative } & $19 \%$ \\
\hline & \multicolumn{2}{|c|}{ Negative Imperative } & $43.75 \%$ \\
\hline & \multicolumn{2}{|c|}{ Modal } & $23.19 \%$ \\
\hline & \multicolumn{2}{|c|}{ Indirect Speech } & $5 \%$ \\
\hline & \multicolumn{2}{|l|}{$\mathrm{Be}+\mathrm{Not}+\mathrm{To}$} & $5 \%$ \\
\hline \multirow{2}{*}{ Indirect Prohibition Construction } & Performative & Prohibit/Forbid/Prevent & $20.68 \%$ \\
\hline & Lexical Verbs & Stop/Avoid/Not Allowed & $28 \%$ \\
\hline
\end{tabular}

Tables 7 and 8 above reveal that the average percentage of using negative imperative strategy to express both warning and prohibition is (45.77\%). Also, (32.42\%) of the subjects use modal strategy for both SAs. The use of these two strategies is considerably higher than their use of other strategies. It seems that EFL learners mostly prefer negative imperatives and modals in their endeavour to express the SAs of warning and prohibition.

\subsection{Subjects' Deviation to Warning and Prohibition Related Speech Acts}

The analysis of the subjects' responses to Parts 1 and 2 of the test also manifests that the students commit errors both on the recognition and production levels in their attempts to handle the SAs of warning and prohibition. These errors are due to the overlap of the targeted SAs with other related SAs namely advising, threatening, commanding and requesting. On the recognition level, the analysis of the subjects' choices of Part 1 of the test indicates that the average percentage of the subjects who consider other related SAs as warning amounts to (8\%) as Figure 4 illustrates:

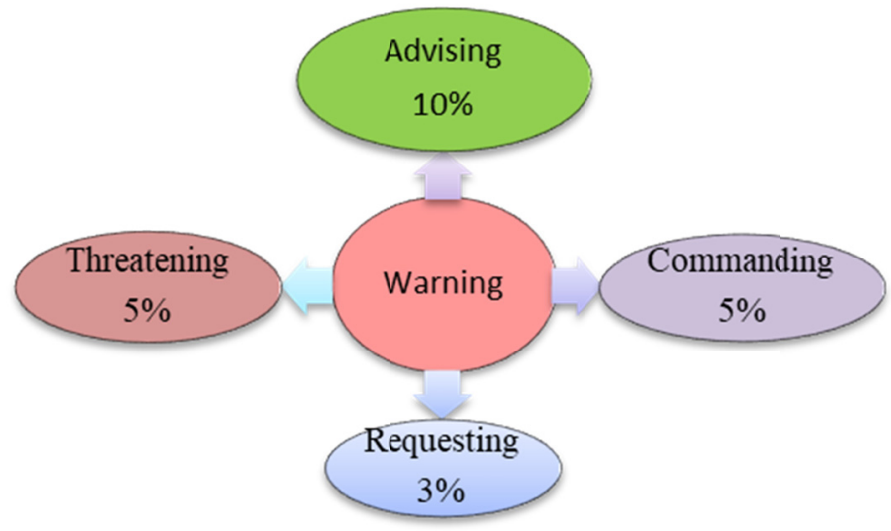

Figure 4. Subjects' recognition overlapping of the SAs of warning with related SAs

On the other hand, the average percentage of the subjects who consider other related SAs as prohibition amounts to $(9.5 \%)$ as illustrated by Figure 5 . 


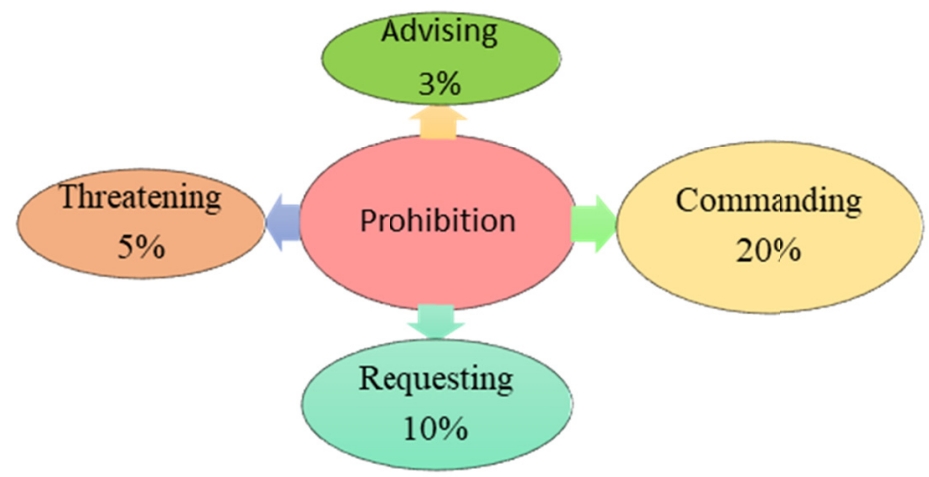

Figure 5. Subjects' recognition overlapping of the SAs of prohibition with related SAs

It is also noted that (13.33\%) of the subjects regard the SA of warning as prohibition, whereas $(30 \%)$ of them consider the SA of prohibition as warning.

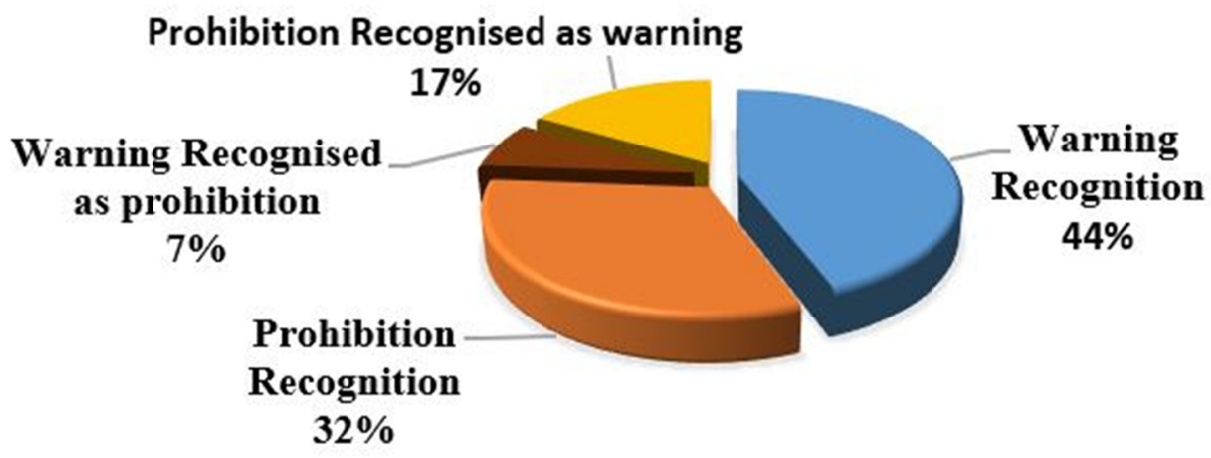

Figure 6. Subjects' recognition overlapping of warning and prohibition

On the production level, (26.66\%) of the students use the SA of advising in expressing the SA of warning. Consider some of the subjects' responses to the following situations where they are required to issue the SA of warning:

Sit.3- If I were you, I would continue my education.

Sit.7- You should do your best in your next match.

Sit.11- I advise you to study carefully.

Also (20\%) of the subjects employ the SA of threatening in their endevour to express the SA of warning. Consider the following are examples of the subjects' responses:

Sit 3-If you don't go to school, I will beat you.

Sit 7- Everyone will be punished if you lose the match.

Sit10- If you are late again, you will leave the company.

Furtherly, (10\%) of the subjects employ the SAs of commanding and requesting in their attempt to produce the SA of warning. The following are examples of the subjects' responses in different situations where they are required to issue the SA of warning.

Sit.13- I want you to stop drinking and eating sweets. (Commanding).

Sit.11- I want you to study hard to pass the exam. (Commanding).

Sit.2- Please, when you go out, tell my parents. (Requesting).

Sit.6- Brush your teeth, please. (Requesting). 
Nevertheless, it is clear that the average percentage of the students who overlap the SA of warning with the SAs of advising and threatening, which is $(23.33 \%)$, is relatively higher than that of their confusing with the SAs of commanding and requesting, which is $(5 \%)$.

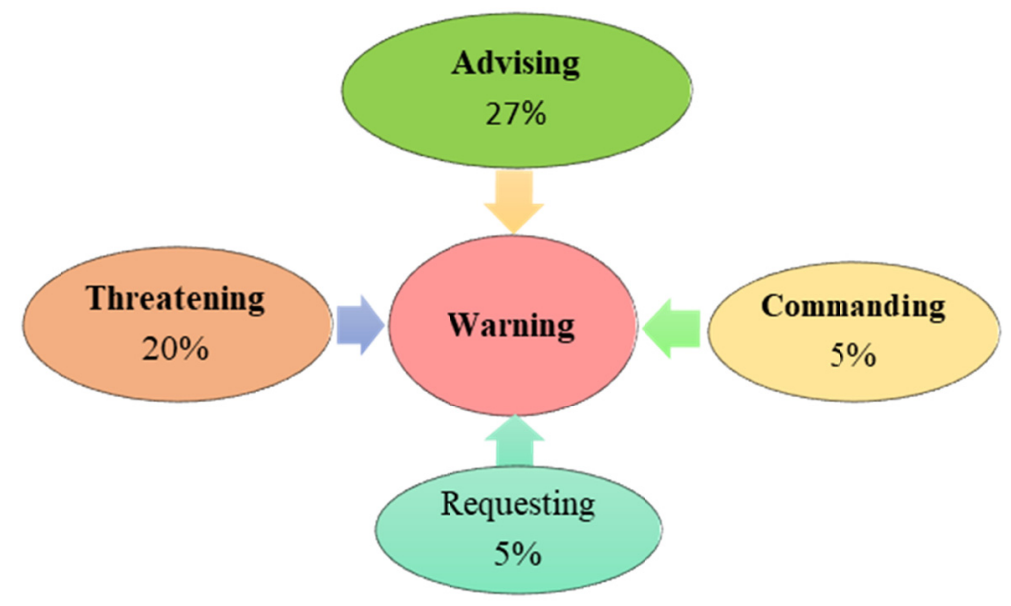

Figure 7. Subjects' production overlapping of the SAs of warning with related SAs

Concerning the subjects' confusion of SA of prohibition with the designated SAs, some of the subjects' responses are also found to be deviant. In expressing the SA of prohibition, (12.33\%) of the students use the SA of advising. Consider some subjects' responses to the following situations where they are required to give the SA of prohibition:

Sit.1- You should drive with your seatbelts on.

Sit.9- You should turn off your cellphone.

Sit.12- You should change these clothes.

Also (11.66\%) of the subjects utilize the SA of threatening in their effort to issue the SA of prohibition. Consider the following examples of the subjects' responses:

Sit.8- If you drive very fast, I will call the police.

Sit.9- If you don't turn off your cellphone, I'll take it.

Sit.12- I will fire you if you do it again.

Additionally, (15\%) of the subjects exploit the SA of commanding in their attempt to produce the SA of prohibition. The following are examples of the subjects' responses in different situations:

Sit 1- Put on your seatbelts when you drive.

Sit 8- I order you to obey the road signs

Sit 12- Obey the rules of school wear.

Finally, (13.33\%) of the subjects use the SA of requesting in their endevour to express the SA of prohibition. Consider the following examples of the subjects' responses:

Sit.9- Switch off your phone, please.

Sit.10- Please, next time don't come late.

Sit.20- would you please lower your voice?

However, it is apparent, as shown in Figure 8 below, that the average percentage of the subjects who confuse the SA of prohibition with the SAs of advising and threatening, which is (12\%), is relatively lower than that of their confusing with the SAs of commanding and requesting, which is (16.67\%). 


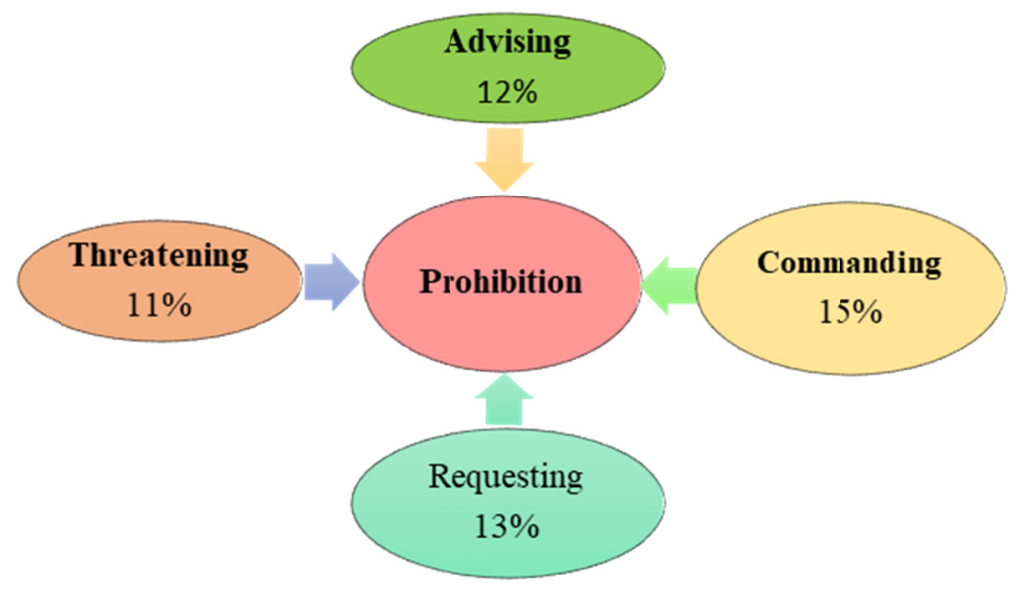

Figure 8. Subjects' production overlapping of the SAs of prohibition with related SAs

The last point to be considered is the students' confusion of the SA of warning with the SA of prohibition. The analysis of subjects' responses to Part 2 of the test reveals that $(11.66 \%)$ of the subjects commit errors by using prohibition strategies to express the SA of warning. Consider the following examples of the subjects' responses where they are asked to produce the SA of warning:

Sit.10- You must not come late again. (Prohibiting)

Sit.14- You can't drive fast. (Prohibiting)

Sit.19- You must not leave your bags unattended. (Prohibiting)

Conversely, $(21.66 \%)$ of the subjects attempt to express the SA of prohibition by means of warning. Consider the following examples of the subjects' responses where they are asked to produce the SA of prohibition

Sit.1- You are in danger because you drive without your seatbelts on. (Warning)

Sit.4- I warn you not to touch father's personal things. (Warning)

Sit.5-If you don't do your homework, you will fail in the exam. (Warning)

The overall overlapping magnitude between warning and prohibition can be summarized by Figure 9 below:

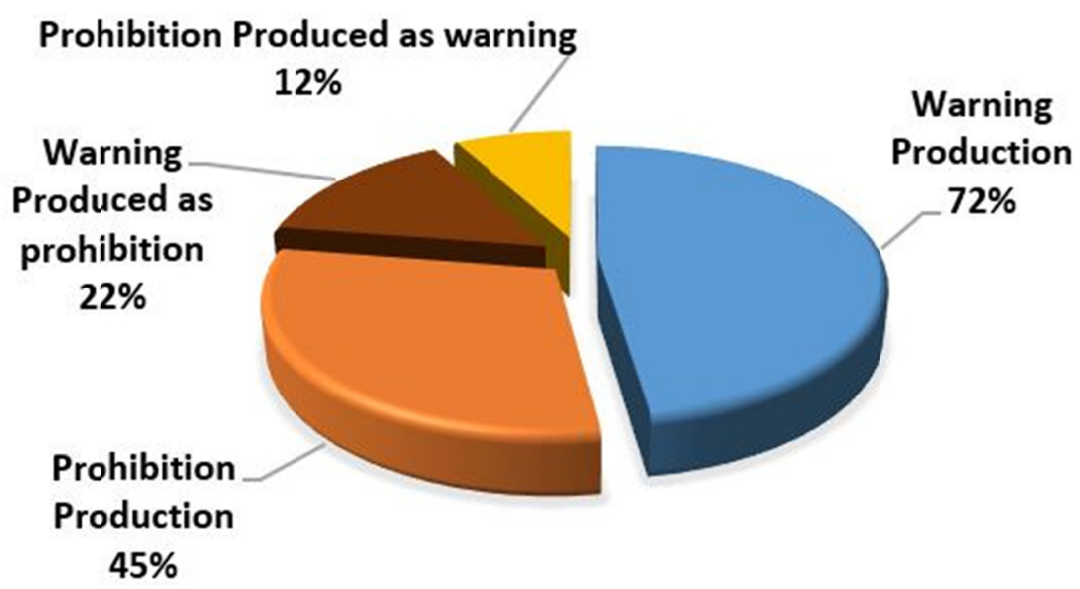

Figure 9. Subjects' production overlapping of warning and prohibition

The students' deviation and failure in recognizing and producing SAs of warning and prohibition can be due to the negative transfer of L1 socio-pragmatic knowledge which is one of the main characteristics that EFL Iraqi students 
employ when attempting to communicate or express the SAs of warning and prohibition. Another factor is that of lexical competence. Most subjects use almost the same or nearly identical constructions to express the SAs of warning and prohibition despite the differences between the given situations. This indicates their limited lexical repertoire that can help them manipulate the choices of linguistic strategies. It can be also said that this confusion is due to the sociopragmatic knowledge that most students lack. This knowledge is mainly attributed to the appropriateness of meaning in terms of the social and cultural contexts in which the SAs are used.

\subsection{Subjects' Awareness of Social Factors}

As far as the SD is concerned, (65.21\%) of the learners tend to express the SA of warning utilizing indirect constructions in the situations of Types A and B, whereas, in Type C situations, only (36.65\%) of them employ the indirect strategies. This indicates that considerable numbers of the subjects are competent users who can cope well with most of the situations in handling the SA of warning with regard to SD. However, the subjects will have occasional misunderstanding especially when warning is overlapped with prohibition.

On the other hand, in expressing the SA of prohibition, the learners behave similarly; in other words, they mostly tend to employ the indirect constructions in the situations of Types A and B which amount to (34\%) is in contrary with their prohibitive behaviour when using the direct strategies which amount to (11\%). However, in Type C situations the subjects behave differently where they tend to use the indirect prohibitive constructions which amount to $(38.73 \%)$, whereas their employment of the direct strategies amount to a poor percentage of $(8.33 \%)$.

The subjects' poor percentage in producing the SA of prohibition in accordance with SD could be due to their limited lexical, syntactic and semantic knowledge of the proper strategies in expressing the SA of prohibition in such circumstances. The most important reason to be mentioned with respect to the subjects' failure in handling the SA of prohibition can be linked to the early stages of learning English where warning and prohibition are treated as an identical phenomenon.

\section{Findings}

The significant conclusions obtained from this study are:

1) The SA of warning can be distinguished from the SA of prohibition according to particular contextual factors. These factors are: Intentionality and purpose, authority and power, optionality, cost- benefit scale, politeness and social factors, and illocutionary force indicating Devices (IFIDs)

2) Iraqi EFL learners' ability to produce both SAs of warning and prohibition is found lower than their ability in recognizing these SAs. This verifies the first hypothesis of the study.

3) The learners have displayed sufficient awareness in identifying and issuing most types of strategies in their performance of the SA of warning in various situations. By contrast, they have shown poor awareness of handling all types of strategies in performing the SA of prohibition. These accords with the second hypothesis.

4) In producing the SAs of warning and prohibition, Iraqi EFL learners show a higher preference for using negative imperative, modals and if-conditional strategies more than other types in most of the situations, whereas in communicating the SA of prohibition, they employ negative imperatives and modals more than any other construction. This verifies the third hypothesis of this study.

5) Iraqi EFL learners also confuse the SAs of warning and prohibition by using other relevant SAs at the recognition and production levels; i.e. using commanding and requesting to communicate prohibition or threatening and advising to convey warning. This confirms the fourth hypothesis.

6) Iraqi EFL learners often resort to the sociocultural norms when they are required to produce the SAs of warning, whereas in producing the SA of prohibition, they are often found to deviate from these norms. This is obvious in their responses to the various situation of $\mathrm{A}$, and $\mathrm{C}$. This indicates that the students are linguistically unaware of the conventions, norms and resources used to express the SA of prohibiting in L2.

7) Mostly, the contextual factors have no significant influence on the learners' choice of the different strategies of the SAs of warning and prohibition. It is found that Iraqi EFL learners are not well acquainted with the factors influencing the choice of language, i.e. Status, Social Distance and Power.

8) The learners' success in identifying the intended SAs of warning and prohibition depends mostly on the degree of the explicitness of the expression used. The more explicit the expression is, the more successful the learners are in recognizing the intended SA.

9) In most of prohibitive situations, Iraqi female EFL learners' behaviour is sometimes characterised by the presence of politeness, i.e. they mostly use "please" either at the beginning or the end of the prohibitive 
construction. Likewise, they also show a high preference for using backup and justification phrases when issuing the SA of warning and prohibition.

10) Most of the utterances produced by EFL students in expressing warning and prohibiting are pragmatically transfered from Iraqi utterances used in spoken situations utilised in everyday Iraqi situations.

\section{Recommendations}

1) It is crucial to help the learners develop awareness for using all types of strategies to express SAs of warning and prohibition and to put choices that are more appropriate at their disposal. The student's syntactic and semantic knowledge should be enhanced and developed by teachers in order to help students produce pragmatically acceptable utterances through practising these various strategies specifically used to express the SAs of warning and prohibition.

2) Promote knowledge of how SAs of warning and prohibition work by constructing a model performance of the SAs of warning and prohibition as they might be realized under differing conditions. on how those two SAs are performed by members of one or more communities of practice within a given speech community (for example, at the workplace, making warning and prohibition by people of the same age, understanding warning and prohibition made by people of higher status and so on).

3) In an effort to avoid pragmatic failure, the learner may identify the sociopragmatic norms for performance of the SAs of warning and prohibition in the target speech community, i.e. the conventional formula that tend to be used with the SAs of warning and prohibition in certain situations (e.g., whether a warning/prohibition is issued with a justification, mitigation, conversational principles, etc.

4) Iraqi EFL learner's repertoire should be enriched with the lexical competence used to represent the SAs of warning and prohibition (e.g. when it is appropriate to use imperatives, negative imperatives, modals, brief announcements and so on). EFL learners should be taught that not all warning/prohibition strategies can be said in all circumstances and there should be contextual conditions to using those strategies appropriately.

\section{Suggestions for Further Studies}

1) A study can be conducted by exploring the use of the SAs of warning and prohibition in a literary piece such as a novel.

2) A study can be conducted by exploring the use of the warning and prohibition signs in Arabic and English in public places in Iraq.

3) A developmental study can be carried out to show a comparison between native and non-native speakers of English in the performance of the SAs of warning and prohibition.

4) A study can be conducted to demonstrate the contrast between females and male students in the performance of the SAs of warning and prohibition.

\section{Acknowledgements}

The authors acknowledge gratitude and appreciation to Mustansiriyah University, College of Arts, English Department for their cooperation and support. Gratitude is to be extended to the Iraqi EFL college fourth-year students for being so helpful in responding to the test. Furthermore, the authors are grateful to the jury members who reviwed the validity and reliability of the test in this study.

\section{References}

Allan, K. (1986). Linguistic Meaning. London: Routledge and Kegan Paul Inc.

Allwood, J. (1976). Linguistic communication as action and cooperation (Doctoral dissertation). University of Göteborg. Department of Linguistics.

Al-Saaidi, S. K., Al-Shaibani, G. K., \& Al-Husseini, H. M. (2013). Speech Act of Prohibition in English and Arabic: A Contrastive Study on Selected Biblical and Quranic Verses. Arab World English Journal, 4, 95-111.

Al-Shafie, R., \& Al-Jubbory, F. (2015). Iraqi EFL learners' Use of the Speech Acts of Warning and Threatening in situational. Adab Al-Kufa, 24, 11-26.

Austin, J. (1962). How to Do Things with Words. Oxford: Oxford University Press.

Betti, M. J., Igaab, Z. K., \& Al-Ghizzi M. T. (2018). Iraqi EFL Learners' Use of Permission, Obligation and Prohibition. International Journal of English Linguistics, 8(3), 251-269. https://doi.org/10.5539/ijel.v8 n3p251 
Binnick, R. I. (1991). Time and the Verb: A Guide to Tense and Aspect. Oxford: Oxford University Press.

Brown, P., \& Levinson, S. (1979). Universals in Language Usage: Politeness Phenomena. In E. Goody (Ed.) Questions and Politeness (pp. 56-311). Cambridge: Cambridge University Press.

Butler, C. (1985). Statistics in Linguistics. Oxford: Basil Blackwell.

Corder, S. P. (1982). Error Analysis and Interlanguage. Oxford: Oxford University Press.

Creswell, J. W. (2012). Educational Research: Planning, Conducting, and Evaluating Quantitative and Qualitative Research. USA: Pearson Education.

Crocker, L., \& Algina, J. (1986). An Introduction to Classical and Modern Test Theory. New York: Holt, Rinehart and Winston.

Cruse, A. (2000). Meaning in Language. Oxford: Oxford University Press.

Crystal, D. (2010). The Cambridge Encyclopedia of Language (3rd ed.). Cambridge: Cambridge University Press.

Davies, E. (1986). The English Imperative. London: Croom Helm.

Eastwood, J. (2002). Oxford Guide to English Grammar. Oxford: Oxford University Press.

Finch, G. (2000). Linguistic Terms and Concepts. Britain: Blackwell publishing Ltd. https://doi.org/10.1007/97 8-1-349-27748-3

Fraser, B. (1998). Threatening Revisited. Journal of Forensic Linguistics, 5, 159-173. https://doi.org/10.155 8/sll.1998.5.2.159

Geis, M. L. (2006). Speech Acts and Conversational Interaction. Cambridge: Cambridge University Press.

Goddard, C. (2011). Semantic Analysis: A Practical Introduction (2nd ed). Oxford: Oxford University Press.

Goddard, C., \& Wierzbicka, A. (2013). Words and meanings: Lexical semantics across domains, languages, and cultures. Oxford: Oxford University Press. https://doi.org/10.1093/acprof:oso/9780199668434.001.0001

Green, M. (n.d.) Visual Expert Human Factors: The Psychology of Warnings. Retrieved February 12, 2018, from http://www.visualexpert.com/Resources/psychwarnings.html

Griffiths, P. (2006). An Introduction to English Semantics and Pragmatics. Edinburgh: Edinburgh University Press.

Hatch, E., \& Farhady, H. (1982). Research Design and Statistics for Applied Linguistics. Cambridge: Newbury House Publishers.

Halliday, M. A. K. (1973). Explorations in the Functions of Language. London: Edward Arnold.

Harris, D. (1969). Testing English as a Second Language. New York: McGrow-Hill Inc.

Harrison, A. (1983). A Language Testing Handbook. London: Macmillan Press.

Haverkate, H. (1979). Impositive Sentence in Spanish: Theory and Description in Linguistic Pragmatics. Amsterdam: North-Holland Publishing Company.

Heaton, J. (1988). Writing English Language Tests: A Practical Guide for Teachers of English as a Second or Foreign Language. London: H. Charles and Co. Ltd.

Jespersen, O. (2007). Essentials of English Grammar. Delhi: Henry Holt and Company, Inc.

Kadhim, W. (2012). A Pragmatic Analysis of Threat and Warning in English and Arabic Selected Religious Texts: Contrastive Analysis. (Unpublished master's thesis). University of Baghdad, Ibn-Rushed, Baghdad.

Leech, G. (1983). Principles of Pragmatics. London: Longman Group Limited.

Leech, G., \& Svartvik, J. (1994). A Communicative Grammar of English. London: London Group, Ltd.

Levinson, S. (1983). Pragmatics. Cambridge: Cambridge University Press. https://doi.org/10.1017/CBO97805 11813313

Lyons, J. (1977). Semantics: Vol. 1 And 2. Cambridge: Cambridge University Press. https://doi.org/10.1017/CBO 9781139165693

Mayor, M. (2013). Longman Collocations Dictionary and Thesaurus. Harlow, Essex: Pearson Education.

Mousavi, S. A. (1999). A Dictionary of Language Testing. Tehran: Rahnama Publications.

Olshtain, E., \& Cohen, A. D. (1983). Apology: A Speech Act Set. In N. Wolfson, \& E. Juddie (Eds.), 
Sociolinguistics and Language Acquisition (pp. 18-35).

Quirk, R., Greenbaum, S., Leech, G., \& Svartvik, J. (1985). A Comprehensive Grammar of the English Language. London: Longman Group, Ltd.

Radden, G. (2014). Making sense of negated modals. Argumentum, 10, 519-532.

Sadock, J. M. (1974). Toward a linguistic theory of speech acts. London: Academic Pr.

Searle, J. R. (1969). Speech Acts: An Essay in the Philosophy of Language. Cambridge: Cambridge University Press. https://doi.org/10.1017/CBO9781139173438

Searle, J. R., \& Vanderveken, D. (1985). Foundation of Illocutionary Logic. New York: Cambridge University Press.

Spring, D. (1999). Negative Imperative. Lesson (29) www.Google.com: 1-2.

Swan, M. (2005). Practical English Usage. Oxford: Oxford University Press.

Thomson, A. J., \& Martinet, A. V. (1986). A Practical English Grammar. Oxford: Oxford University Press.

Trask, R. (1993). A Dictionary of Grammatical Terms in Linguistics. London: Routledge Inc.

Wierzbicka, A. (1987). English Speech Act Verbs: A Semantic Dictionary. Sydney: Academic Press.

Wolfson, N. (1989). Perspectives, Sociolinguistics and TESOL. Boston: Heinle \& Heinle.

Yule, G. (1996). Pragmatics. Oxford: OUP.

\section{Appendix A: The Test}

Dear respondent,

The researcher is conducting a study entitled "Iraqi EFL College Students' Performance of the Speech Acts of Warning and Prohibition". I kindly appreciate your participation by answering these questions carefully and accurately. This research is intended for educational use only, and the information you provide will be kept confidential.

Thank you.

The Researcher

\section{General Information}

Sex:

male female

Age:

\section{Part One: Recognition}

Q// Read the following situations carefully and then choose what you believe to be the intended speech act conveyed by the given utterance. Please circle the letter of the correct choice:

1) A kind-hearted manager addresses his secretary who has been working overtime for three months by saying:

If you go on like this, you'll make yourself ill.
a. threatening
b. warning
c. prohibiting
d. commanding

2) A tourist asks the travel agency about the security of the city he is visiting. The clerk says to him:

Don't go outside at night because it might be dangerous.

a. warning

b. prohibiting 


\section{c. commanding}

\section{d. threatening}

3) In the classroom, the students who have a lecture are talking with each other and making noise. The teacher addresses them:

Don't make noise, will you?
a. threatening
b. prohibiting
c. requesting
d. warning

4) To avoid the danger of careless medicine treatment, all medicines contain such notification:

Keep out of the reach of the children.
a. requesting
b. warning
c. prohibiting
d. commanding

5) At work, Mary's workmate sees that Mary keeps working hard though she looks exhausted. She says to her:

Have some rest, can't you?
a. advising
b. prohibiting
c. warning
d. commanding

6) You are trying to fix the ceiling fan at home. Your eldest sister helps you by holding the ladder and says: Mind your head!
a. requesting
b. prohibiting
c. advising
d. warning

7) Sam's neihbours are having a party and playing very loud music in their next-door apartment, which causes Sam to be annoyed. So he speaks to them:

If you don't turn your music down, I'll call the police!
a. warning
b. advising
c. prohibiting
d. threatening

8) A seller is explaining how to deal with the new product:

For your safety, please, read the instructions carefully before you turn on the machine.
a. threatening
b. prohibiting 


\section{c. requesting}

\section{d. warning}

9) John is helping his friend Sam parking his car at a garage. John notices that Sam is unaware of the broken glass on the ground behind him, thus he immediately shouts:

Watch out! There's broken glass everywhere!
a. warning
b. commanding
c. threatening
d. prohibiting

10) In a lecture on climate change, the speaker alertes his audience that:

Scientists have warned us about the effects of climate change.
a. commanding
b. warning
c. advising
d. prohibiting

11) At the airport, you abide by security procedures. The X-ray machine operator suspects that you carry forbidden materials inside your suitcase. So he says:

Will you please open the suitcase?
a. prohibiting
b. warning
c. requesting
d. commanding

12) Mary notices that some children are playing around an electric outlet and touching it. She tells them: You should not play here.
a. prohibiting
b. threatening
c. warning
d. requesting

13) Lucy is trying to park her car where cars are not allowed to park. The traffic policeman says to her: You are not allowed to park in here.
a. prohibiting
b. commanding
c. warning
d. requesting

14) When there is a crime somewhere in a town, the police secure the area with a tape and put this note:

No trespassing

a. prohibiting

b. warning 


\section{c. requesting}

d. commanding

15) At the university where Matilda works as a typist, the manager hands her an important paper and says:

I want this paper to be typed today.
a. commanding
b. prohibiting
c. requesting
d. warning

16) In a hospital, a nurse notices two men smoking cigarettes in the hallway. She says to them:

You may not smoke in here.
a. warning
b. commanding
c. prohibiting
d. advising

17) You are missing your sister Sandy whose age is a thirty month. Fortunately, after a while, you see this child trying to climb the stairs. You are concerned that she might hurt herself and so you speak:

I forbid you to climb the stairs.
a. warning
b. commanding
c. prohibiting
d. advising

18) In a medical clinic, a doctor speaks with one of his patients who has been taking medicine for two months. You must stop taking this medicine.
a. threatening
b. prohibiting
c. requesting
d. warning

19) Bob is sitting in his reading room. His eldest son suddenly enters the room during his reading. He says to his son:

You are not to come into my room without knocking the door.
a. commanding
b. threatening
c. prohibiting
d. warning

20) In a final exam, one of the students tries to cheat. At the same time one of the teachers noticed him, so he speaks loudly:

Cheating is prevented.

a. advising 


\section{b. prohibiting \\ c. commanding \\ d. warning}

21) David has an important exam next Wednesday. His uncle, Andrew, invites David to a party the night before. David's father addresses him:

I advise you to stay at home next Wednesday.
a. threatening
b. requesting
c. advising
d. prohibiting

22) Mary is using her computer and there is a long wire connected to the computer. She notices that her little brother is playing a toy car behind the computer, so, she says:

I warn you not to touch that wire.
a. threatening
b. warning
c. advising
d. prohibiting

23) During a safari journey arranged by the university for the students to the adventure the wild life, one of the students notices something on a tree and shouts:

There is a snake on the tree.
a. threatening
b. warning
c. advising
d. prohibiting

24) You are visiting a sick friend at the city hospital. At the main entrance, you see the following notice:

This hospital is a NON-SMOKING area.
a. prohibiting
b. commanding
c. requesting
d. warning

25) While you are driving on the highway, you notice the following sign on the rear of a tank trailer:

Danger! Flammable liquids.
a. prohibiting
b. threatening
c. advising
d. warning 


\section{Part Two}

\section{Production: Strategies Used for Expressing the Speech Acts of Warning and Prohibition}

Q// Use the appropriate utterance to issue the speech acts of warning and prohibition according to the following situations:

1) Prohibit your brother from driving without his seat belts on.

2) Your teenage brother usually leaves home without informing your parents where he is going and with whom. Warn him?

3) Your young sister does not want to continue her school education. What would you say to warn her?

4) Mary discovers that her little sister plays with her father's personal things during his absence. Mary forbids her sister:

5) Prevent your younger brother from neglecting his homework?

6) At night, you notice that your youngest brother goes to sleep without brushing his teeth. What would you say to warn him?

7) You are a football team coach. You see that the team players are not training hard enough. You think that they may lose the next match. How would you warn them? 
8) You own a car hire company, you notice that one of your drivers drives very fast, and does not obey the signs on the roads. What would you say to forbid him?

9) You are a teacher. You notice that one of your students is using his cellphone during the lecture. What would you say to prohibit him?

10) You are the head of a company. You notice that some of your employees come late to work. Warn them:

11) A teacher urges his students to study hard for their exams. He warns them that:

12) Mary is a school headmistress. She notices a girl student wearing strange clothes, which is against the rules. She forbids her:

13) A doctor warns his patient about sugary drinks and sweets. The doctor says:

14) You see your friend walking in the street and a speedy car is coming towards him. Warn him.

15) You are at work, and the lift is broken. You are concerned that somebody might use the lift and get stuck inside it. What would you say to warn your co-workers and the customers. 
16) Some of your friends use unsuitable language while talking to those who are older than they are. Forbid them.

17) You work as a financial employee in a bank. Your close friend Sam visits you at your work and suddenly he tries to have a look at the papers lying in front of you. Prohibit him:

18) You notice that one of your classmates, whose desk is in front of yours, is writing on the classroom wall. What would you say to prohibit him?

19) You notice that some of your colleagues leave their bags unattended at the college canteen and go out. What would you say to warn them?

20) Some students are talking loudly in the library while you are studying there. What would you say to prohibit them?

Thanks for your time.

\section{Appendix B: The Jury Members}

The Jury of experts consisted of the following members arranged according to the scientific rank and alphabetically:

1) Prof. Riyadh K. Ibraheem, Ph.D. in English Language and Linguistics, College of Languages / University of Baghdad.

2) Prof. Sabah S. Mustafa, Ph. D. in English Language and Linguistics, College of Languages / University of Baghdad.

3) Asst. Prof. AbdulKareem Fadhil, Ph.D. in English Language and Linguistics, College of Education (Ibn Rushd)/ University of Baghdad.

4) Asst. Prof. Ahmed S. Hussein, Ph. D. in English Language and Translation, College of Arts / Mustansiriya University.

5) Asst. Prof. Istiqlal H. Ja'fer, Ph. D. in Applied Linguistics, College of Arts / Mustansiriya University. 
6) Asst. prof. Sameer S. Al-Dihawi, Ph. D. in Linguistics and Translation, College of Arts / Mustansiriya University.

7) Asst. Prof. Bayda' A. Lateef, Ph. D. in Linguistics and Translation, College of Arts / Mustansiriya University.

8) Asst. prof. Nadia M. Hussein, Ph. D. in Applied Linguistics, Middle Technical University.

9) Inst. Ali Arif, Ph. D. in English Language and Linguistics, College of Languages / University of Baghdad.

10) Inst. Thulfiqar H. Muhi, Ph. D. in English Language Linguistics, College of Arts / Mustansiriya University.

11) Inst. Mohammed Hassan, Ph. D. in English Language Linguistics, College of Arts / Mustansiriya University.

\section{Copyrights}

Copyright for this article is retained by the author(s), with first publication rights granted to the journal.

This is an open-access article distributed under the terms and conditions of the Creative Commons Attribution license (http://creativecommons.org/licenses/by/4.0/). 